\title{
ANALISIS PENILAIAN KESEHATAN KOPERASI SIMPAN PINJAM BERDASARKAN PERATURAN DEPUTI BIDANG PENGAWASAN KEMENTERIAN KOPERASI USAHA KECIL DAN MENENGAH No: 14/Per/DEP.6/IV/2016 PADA KOPERASI PEGAWAI KEJAKSAAN TINGGI SUMATERA SELATAN
}

\author{
Imam Ariansyah \\ Fakultas Ekonomi Universitas PGRI Palembang \\ Email : Imamariansyah413@gmail.com \\ Nurmala \\ Fakultas Ekonomi Universitas PGRI Palembang \\ Email : nurmalabahamid@gmail.com \\ DOI : 10.35908/jeg.v4i2.755
}

Received: May 30, 2019, Revised: June 25, 2019, Accepted: July 15, 2019

\begin{abstract}
This study aims to assess the health level of savings and loan cooperatives based on regulations of the superintendent of the ministry of cooperatives of small and medium enterprises No, 14 / per / DEP.6 / IV / 2016 Padakoperasi high prosecutor's office in South Sumatra. The population in this study is a cooperative financial report, while the sample is the 2016-2018 period financial statement. Discussion of Research Results The Capital Value is obtained a score of 7.1 the average score of 1.50 the highest score with susceptible standards $\leq 51$. get Predicate in Special Supervision. The Product Quality Asset Quality score is scored 10 with an average score of 10 with a score the highest 100 with vulnerable 80 $\leq X \leq 100$. Get a healthy predicate. Efficiency aspect obtained an average score of $3.33 . \%$ Of the maximum score of 4 , the highest score of 100 , with a range of $80 \leq X \leq 100$. Got a healthy predicate, Liquidity Aspect obtained a score of 2.5 with a value of 25 Maximum score of 100, with a standard range rentang 51.00. Obtaining a Predicate under Special supervision, the Aspects of Independence and Growth obtained an average of 2.25 maximum score of 3 in the range of $66 \leq X \leq 80$. Self-Aspect score $=$ average 7 with a maximum score of 7 where the ratio is obtained with a standard range of 80 $\leq \mathrm{X} \leq 100$. Get healthy predicate.
\end{abstract}

Keywords: Capital Aspect, earning assets, efficiency, liquidity, independence and growth, identity

\begin{abstract}
ABSTRAK
Penelitian ini bertujuan untuk menilai tingkat kesehatan koperasi simpan pinjam berdasarkan peraturan deputi bidang pengawasan kementerian koperasi usaha kecil dan menengah No,14/per/DEP.6/IV/2016 Pada koperasi pegawai kejaksaan tinggi Sumatera Selatan.Populasi dalam penelitian ini adalah Laporan keuangan koperasi, sedangkan sampelnya adalah laporan keuangan priode 2016-2018 Pembahasan Hasil PenelitianAspek Permodalan diperoleh skor sebesar 7,1 skor rata-rata 1,50 skor tertinggi100dengan rentan standar $\leq$ 51.mendapat Predikat Dalam Pengawasan khusus. Aspek Kualitas Asset Produktif diperoleh skor 10 dengan skor rata-rata 10 dengan skor tertinggi 100 dengan rentan $80 \leq \mathrm{X} \leq 100$. Mendapat predikat sehat. Aspek Efisiensi diperoleh ratarata skor3,33.\% skormaksimal 4 nilai tertinggi 100, dengan rentang $80 \leq X \leq 100$. mendapat predikat sehat, Aspek Likuiditas diperoleh skor 2,5dengan nilai 25 Skor maksimal 100, dengan standar rentang $\leq 51,00$.Mendapat Predikat dalam pengawasan Khusus, Aspek Kemandirian dan Pertumbuhan diperoleh rata-rata 2,25 skor maksimal 3 dalam rentang $66 \leq X \leq 80$.mendapat Predikat cukup sehat. Aspek Jati Diri skor rata=rata 7 dengan skor maksimal 7 dimana rasio diperoleh berada dengan standar rentang $80 \leq \mathrm{X} \leq 100$. Mendapat Predikat sehat.
\end{abstract}


Kata Kunci: Aspek Permodalan, Aktiva produktif, efisiensi, likuiiditas, kemandirian dan Pertumbuhan, Jati diri.

\section{Pendahuluan}

Koperasi sebagai salah satu bentuk dari badan usaha non profit dengan memanfaatkan sumber daya ekonomi dari anggotanya diharapkan dapat berperan aktif membantu pihak pemerintah dalam pembangunan ekonomi masyarakat secara keseluruhan, yang mana keberadaan koperasi saat ini sangat dirasakan manfaatnya oleh masyarakat yang tergabung dalam keanggotaan koperasi, hal ini dapat dilihat dari semakin menggeliatnya perekonomian masyarakat yang didapat oleh anggota koperasi setelah bergabung menjadi anggota koperasi.

Sebagai toko guru dari tiga pilar pembangunan ekonomi di Indonesia peran koperasi sebagaimana tertuang dalam amanat Undang-undang dasar 1945 pasal 33 ayat 1 yang berbunyi bahwa “" Perekonomian disusun sebagai usaha bersama berdasarkan atas azas kekeluargaan dan ayat 4 menyatakan bahwa " Perekonomian nasional disusun sebagai usaha bersama berdasarkan atas demokrasi ekonomi dengan prinsip kebersamaan, efisiensi, berkeadilan, berkelanjutan, berwawasan lingkungan, kemandirian serta dengan menjaga keseimbangan kemajuan dan kesatuan ekonomi nasional.

Sesuai dengan amanat undangundang bahwa tujuan dari pembentukan koperasi sebagai bagian dari usaha pembangunaan ekonomi nasional secara menyeluruh karena koperasi dibangun berdasarkan peran serta dari seluruh anggota yang ikut serta berpartisipasi dalam menanamkan modal usaha berupa iuran wajib dan sukarela dengan tujuan untuk membantu membangun usaha dengan pelayanan atas asas kekeluargaan yang sesuai dengan prinsif demokrasi ekonomi.

Koperasi berperan positif dalam pembangunan nasional di Indonesia baik secara langsung maupun tidak langsung, namun dalam perkembangan dan pertumbuhan koperasi masih belum menunjukkan hasil sesuai dengan efektasi yang diinginkan anggota koperasi untuk memakmurkan seluruh anggotanya, hal ini dikarenakan disebabkan banyaknya bidang usaha yang dikelolah dalam koperasi dan rata-rata mereka yang dilibatkan dalam kepengurusan koperasi memiliki pekerjaan tetap di kantor, sehingga kepengurusan koperasi belum dilaksanakan secara maksimal dengan demikian tujuaan untuk memakmurkan anggota sulit terealisasi. Selama ini belum sepenuhnya tercapai menampakan wujud dan peranannya, karena masih belum tercapai peran koperasi terhadap kemakmuran anggota secara maksimal.

Koperasi adalah salah satu bentuk usaha berbadan hukum yang berdiri di Indonesia. Menurut undang-undang Nomor 25 Tahun 1992 Bab 1 Pasal 1 tentang perkoperasian, koperasi adalah badan usaha yang beranggotakan orang seorang atau badan hukum koperasi berlandaskan kegiatannya berdasarkan prinsip koperasi sekaligus sebagai gerakan sebagai ekonomi rakyat yang berdasarkan atas asas kekeluargaan. Keberadaan koperasi di Indonesia diharapkan mampu memberikan solusi akan masalah yang dihadapi masyarakat di Indonesia, 
khususnya dapat membantu dari sisi kebutuhan akan modal.

Untuk melihat kinerja koperasi diperlukan maka umumnya juga memerlukan suatu alat yang dapat digunakan untuk mengetahui kinerja keuangan koperasi agar pihak koperasi dapat melaksanakan tugas dan kewajibannya dengan baik sesuai tujuan koperasi pada umumnya. Koperasi merupakan salah satu bentuk organisasi ekonomi yang mendapat perhatian pemerintah. Koperasi merupakan organisasi yang berbadan hukum.

Tujuan Koperasi Dalam UU No. 25/1992 tentang perkoperasian pasal 3 disebutkan, "Koperasi bertujuan memajukan kesejahteraan anggota pada khususnya dan masyarakat pada umumnya, serta ikut membangun tatanan perekonomian nasional, dalam rangka mewujudkan masyarakat yang maju, adil, dan makmur berlandaskan Pancasila dan UU1945". Koperasi simpan pinjam kejaksaan tinggi melakukan penghimpunan dana dari para anggota dalam bentuk simpanan poko, wajib, cadangan dan donasi.

Dana yang dihimpun nantinya akan digunakan untuk meningkatkan permodalan yang akan disalurkan kepada para anggota dalam bentuk kredit. Kredit tersebut umumnya akan dipergunakan oleh anggota untuk modal atau konsumsi. Melalui kegiatan ini koperasi simpan pinjam kejaksaan tinggi akan memperoleh SHU (Sisa Hasil Usaha) yang akan dibagikan kepada para anggotanya setiap akhir tahun. Sebagai salah satu badan usaha koperasi harus bisa mengontol penggunaan modal dalam koperasinya agar dapat meningkatkan efisiensi koperasi. Keberhasilan dalam penggunan modal dapat dilihat dari rentabilitas koperasi.

Laporan keuangan adalah instrument yang tepat untuk dijadikan bahan analisa kinerja koperasi Kejaksaan Tinggi dari tahun ketahun berikutnya, karena dalam laporan keuangan terdapat informasi penting seperti sumber daya perusahaan, kewajiban /hutang, hutang dan kekayaan pemilik. Dalam mengadakan analisa dan evaluasi terhadap laporan keuangan akan dapat diketahui keadaan keuangan perusahaan juga perkembangan keuangannya. Disamping itu dapat di ketahui kelemahan-kelemahan yang masih ada.

Kinerja keuangan koperasi dapat dilihat dari laporan keuangan perusahaan terdiri dari neraca dan laporan rugi laba, merupak laporan yang menunjukan kondisi keuangan perusahaan yang terdiri dari asset, hutang, modal, dan hasil usaha. Salah satu cara untuk mengetahui kondisi perkembangan suatu usaha itu dengan menggunakan rasio.

Berdasarkan uraian diatas, maka penulis tertarik untuk melakukan penelitian dengan judul "Analisis Penilaian Kesehatan Koperasi Simpan Pinjam berdasarkan Peraturan Deputi Bidang Pengawasan Kementerian Koperasi Usaha Kecil Dan Menengah Nomor : 14/Per/DEP.6/IV/2016 Pada Koperasi Pegawai Kejaksaan Tinggi Sumatera Selatan".

Untuk menghindari agar penelitian ini tidak menyimpang dari pokok permasalahan yang ada, maka penulis membatasi pembahasan penelitian ini menggunakan peraturan menteri Negara Usaha Kecil dan Menengah Republik 
Indonesia, hanya menilai tingkat kesehatan Koperasi, Simpan Pinjam yang meliputi penilaian terhadap beberapa aspek sebagai berikut, Permodalan, Kualitas Aktiva Produktif, Efisiensi, Likuiditas, Kemandirian dan Pertumbuhan, Jatidiri Koperasi.

Berdasarkan latar belakang yang diuraikan diatas, maka rumusan masalah dalam penelitian ini adalah Bagaimana Penilaian Tingkat Kesehatan Koperasi Simpan Pinjan Berdasarkan Peraturan Kementerian Koperasi Usaha Kecil dan Menegah Republik Indonesia Nomor :06/Per/6/IV/2016 Pada Pegawai Kejaksaan Tinggi Sumatera Selatan periode 2016-2018?.Adapun tujuan dari penelitian ini untuk menilai Tingkat kesehatan Koperasi Simpan Pinjam pada koperasi Pegawai Kejaksaan Tinggi Sumatera Selatan periode 2016-2018.

\section{TINJAUAN TEORI}

\section{Pengertian Kinerja Keuangan}

Menurut Fahmi (2012:2) bahwa kinerja keuangan merupakan suatu analisis yang dilakukan untuk melihat sejauh mana suatu perusahaan telah melaksanakan dengan menggunakan aturan-aturan pelaksanaan keuangan secara baik dan benar. Kinerja keuangan merupakan hasil dari suatu proses akuntansi untuk membantu memecahkan dan sekaligus menjawab masalah-masalah yang timbul dalam suatu organisasi perusahaan maupun organisasi yang tidak bertujuan mencari laba, banyak keputusan individual yang dibuat secara terus menerus oleh manajemen.

Kinerja merupakan suatu kondisi yang harus diketahui dan dikonfirmasikan kepada pihak tertentu untuk mengetahui tingkat pencapaian hasil suatu instansi dihubungkan dengan visi yang diemban suatu organisasi atau perusahaan serta mengetahui dampak positif dan negatif dari suatu kebijakan operasional.

\section{Pengertian Laporan Keuangan}

Menurut Kasmir (2012:7), laporan keuangan adalah laporan yang menunjukkan kondisi keuangan perusahaan pada saat ini atau dalam suatu periode tertentu Laporan keuangan meliputi bagian dari proses keuangan. Laporan keuangan yang lengkap biasanya meliputi neraca, laba rugi, laporan perubahan ekuitas, laporan perubahan posisi keuangan (yang dapat disajikan dalam berbagai cara misalnya, sebagai laporan arus kas / laporan arus dana), catatan dan laporan lain serta materi penjelasan yang merupakan bagian integral dari laporan keuangan. Menurut Kasmir (2012:7), laporan keuangan adalah laporan yang menunjukkan kondisi keuangan perusahaan pada saat ini atau dalam suatu periode tertentu.

\section{Pengertian Koperasi}

Koperasi Menurut Undang-Undang No. 25 Pasal 1 tahun1992, adalah badan usaha yang beranggotakan orang-orang atau badan hukum koperasi dengan melandaskan kegiatannya berdasarkan prinsip koperasi sekaligus sebagai gerakan ekonomi rakyat yang berdasarkan atas asas kekeluargaan.

Sedangkan menurut Rudianto (2010:4) yang dimaksud dengan koperasi adalah suatu perkumpulan orang yang secara sukarela mempersatukan diri untuk 
berjuang meningkatkan kesejahteraan ekonomi mereka melalui pembentukan sebuah badan yang dikelola secara demokratis. Dengan beberapa definisi diatas, peneliti dapat menarik kesimpulan dari pengertian koperasi adalah kerjasama dari orang-orang dalam suatu bentuk usaha yang berbadan hukum dengan menjalankan usaha secara bersama-sama berdasarkan prinsip-prinsip kekeluargaan untuk meningkatkan kesejahteraan anggota.

\section{Penggolongan Koperasi}

Menurut UU No. 25 tahun 1992, ada 4 jenis koperasi berdasarkan kegiatan usahanya, yaitu :

1. Koperasi Simpan Pinjam (KSP) adalah koperasi yang memiliki usaha tunggal yaitu menampung simpanan anggota dan melayani pinjaman. Anggota yang menabung (menyimpan) akan mendapat imbalan jasa dan bagi peminjam dikenakan jasa.

2. Koperasi Serba Usaha (KSU) adalah koperasi yang bidang usahanya bermacam-macam. Misalnya, unit usaha simpan pinjam, unit pertokoan untuk melayani kebutuhan anggota juga masyarakat, unit produksi juga wartel.

3. Koperasi Konsumsi adalah koperasi yang bidang usahanya menyediakan kebutuhan sehari-hari anggota, kebutuhan yang dimaksud misalnya kebutuhan bahan makanan, pakaian, parabotan rumah tangga.

4. Koperasi Produksi adalah koperasi yang bidang usahanya membuat barang (memproduksi) dan menjuala secara bersama-sama. Anggota koperasi ini umumnya sudah memiliki usaha dan

melalui koperasi para anggota
mendapat bantuan modan dan
pemasaran.

\section{Prinsip Koperasi}

Berdasarkan UU No 17 Tahun 2012 pasal 6 ayat 1 , tentang prinsip koperasi yaitu :

a. Koperasi melaksanakan prinsip koperasi yang meliputi :

1) Keanggotaan koperasi bersifat sukarela dan terbuka.

2) Pengawasan oleh anggota diselenggarakan secara demokratis.

3) Anggota berpartisipasi aktif dalam kegiatan ekonomi koperasi.

4) Koperasi merupakan badan usaha swadaya yang otonom dan independen.

5) Koperasi menyelenggarakan pendidikan dan pelatihan bagi anggota, pengawas, pengurus, dan karyawannya, serta memberikan informasi kepaa masyarakat tentang jati diri, kegiatan dan kemanfaatan koperasi.

6) koperasi melayani anggota secara prima dan memperkuat gerakan koperasi dengan bekerja sama melalui jaringan kegiatan pada tingkat lokal. Nasional, regional, dan internasional

7) Koperasi bekerja untuk pembangunan berkelanjutan bagi lingkungan dan masyarakat melaui kebijakan yang disepakati oleh anggota

8) Prinsip koperasi sebagaimana dimaksud pada ayat 1 adalah menjadi sumber inspirasi dan menjiwai secara keseluruhan organisasi dan kegiatan usaha koperasi sesuai dengan maksud dan tujuan pendiriannya.

\section{Fungsi dan Peran Koperasi}

Menurut Muljono (2013:3) fungsi koperasi adalah 
a. Memberi keuntungan kepada anggota melalui Sisa Hasil Usaha (SHU)

b. Mengembangkan usaha anggota Koperasi

c. Meniadakan praktek rentenir.

Sedangkan peran koperasi menurut Muljono adalah :

a. Membangun dan mengembangkan potensi dan kemampuan ekonomi anggota pada khususnya dan masyarakat untuk meningkatkan kesejahteraan ekonomi dan sosial.

b. Berperan serta secara aktif dalam upaya menaikan kualitas kehidupan manusia dan masyarakat.

c. Memperkokoh perekonomian rakyat sebagai dasar kekuatan perekonomian nasional koperasi.

d. Berusaha untuk mewujudkan dan mengembangkan perekonomian nasional yang merupakan usaha bersama berdasarkan atas asas kekeluargaan dan demokrasi ekonomi.

\section{Tingkat Kesehatan Koperasi}

Tingkat kesehatan koperasi merupakan suatu tolak ukur untuk kondisi ataupun keadaan koperasi pada suatu periode tertentu. Pada koperasi simpan pinjam, pengukuran tingkat kesehatan koperasi juga diperlukan guna melihat ataupun mengetahui bagaimana kondisi ataupun keadaan dari koperasi simpan pinjam tersebut. Penilaian tingkat kesehatan kopersi simpan pinjam dapat dinilai berdasarkan beberapa aspek atau beberapa indikator yang sudah ditentukan.

\section{Penilaian Kesehatan Koperasi}

Berdasarkan Peraturan Deputi Bidang Pengawasan Kementerian Koperasi Usaha Kecil Dan

Menengah Nomor: 14/Per/DEP.6/IV/2016 dan Peraturan Menteri KUKM/No. 14/Per/M.KUKM/XII/2009, kesehatan KSP adalah "kondisi atau keadaan koperasi yang dinyatakan sehat, cukup sehat, kurang seahat, tidak sehat dan sangat tidak sehat". Dijelaskan dalam Peraturan Menteri Negara Koperasi dan UKM Nomor 21/Per/M.KUKM/XI/2008, bahwa penilaian kesehatan KSP adalah penilaian terhadap ukuran kinerja KSP dilihat dari 7 Aspek Penilaian yang mempengaruhi kelancaran, keberhasilan, pertumbuhan dan perkembangan serta keberlangsungan usaha KSP dalam jangka pendek dan jangka panjang”.

Penilaian kesehatan koperasi sangat diperlukan untuk mengetahui kondisi tingkat kesehatan sehingga koperasi dapat mengambil keputusan yang hendak diambil untuk kemajuan koperasi selanjutnya. Ruang lingkup penilaian kesehatan KSP meliputi penilaian terhadap beberapa aspek sebagai berikut: 
Tabel 1

Standar Penilaian Kesehatan Berdasarkan KSP/USP Perdep No 06/Per/Dep.6/IV/2016

\begin{tabular}{|c|c|c|c|c|}
\hline No & Aspek yang Dinilai & Komponen & \multicolumn{2}{|c|}{$\begin{array}{c}\text { Bobot Penilaian } \\
\text { (dalam\%) }\end{array}$} \\
\hline 1 & \multirow[t]{2}{*}{ Permodalan } & $\begin{array}{l}\text { a. Rasio modal sendiri terhadap total asset } \\
\qquad \frac{\text { modal sendiri }}{\text { Total aset }} \times 100 \%\end{array}$ & 6 & \multirow[b]{2}{*}{12} \\
\hline & & $\begin{array}{l}\text { b. Rasio modal sendiri terhadap pinjaman diberikan } \\
\text { yang berisiko } \\
\frac{\text { modal sendiri }}{\text { pinjaman diberikan berisiko }} \times 100 \%\end{array}$ & 6 & \\
\hline 2 & $\begin{array}{c}\text { Kualitas aktiva } \\
\text { produktif }\end{array}$ & $\begin{array}{l}\text { a. Rasio volume pinjaman pada anggota terhadap } \\
\text { volume pinjaman diberikan } \\
\frac{\text { Volume Pinjaman Pada Anggota }}{\text { Volume Pinjaman }} \text { X 100\% }\end{array}$ & 10 & 10 \\
\hline 3 & Efisiensi & $\begin{array}{l}\text { a. Rasio beban usaha terhadap SHU kotor } \\
\qquad \frac{\text { beban usaha }}{\text { SHU kotor }} \times 100 \%\end{array}$ & & 4 \\
\hline 4 & Likuiditas & $\begin{array}{l}\text { a. Rasio kas } \\
\qquad \frac{\text { Kas }+ \text { Bank }}{\text { Kewajiban Lancar }} \times 100 \%\end{array}$ & 10 & 10 \\
\hline 5 & $\begin{array}{l}\text { Kemandirian dan } \\
\text { Pertumbuhan }\end{array}$ & $\begin{array}{l}\text { a. Rentabilitas Aset } \\
\qquad \frac{\text { SHU Sebelum pajak }}{\text { Total aset }} \times 100 \%\end{array}$ & & 3 \\
\hline 6 & Jatidiri koperasi & $\begin{array}{l}\text { a. Rasio partisipasi bruto } \\
\qquad \frac{\text { Partisipasi bruto }}{\text { Volume pinjaman }} \times 100 \%\end{array}$ & & 7 \\
\hline
\end{tabular}

Sumber: Permen KUKM No.06/Per/Dep.6/IV/2016

\section{METODE PENELITIAN}

Penelitian ini adalah penelitian deskriptif kuantitatif yang bertujuan untuk menilai kinerja Koperasi Kejaksaan Tinggi Sumatera Selatan yang berlokasi di Jl. Gubernur Hasan Bastari Kav 1 Jakabaring Palembang Populasi dalam penelitian ini adalah laporan keuangan koperasi pegawai kejaksaan tinggi sumsel .sedangkan Sample laporan keuangan priode 2016-2018 koperasi kejaksaan tinggi sumatera selatan. Dengan teknik pengumpulan data dengan study kepustakaan dan dokumentasi dan tekhnik analisa data dalam penelitian 
ini dengan menganalisis data dengan rasio keuangan koperasi.

\section{Jenis-jenis Rasio}

\section{a. Permodalan}

1.Rasio Modal Sendiri Terhadap Total Asset

Rumus : $\frac{\text { Modal sendiri }}{\text { Total aset }}$ X 100\%

2.Rasio Modal Sendiri Terhadap Pinjaman diberikan yang beresiko

Rumus :

$\frac{\text { Modal Sendiri }}{\text { Pinjaman diberikan yang berisiko }}$ X $100 \%$

3. Rasio Kecukupan modal sendiri

Rumus : $\frac{\text { Modal Sendiri }}{\text { ATMR }} \times 100 \%$

\section{b. Kualitas aktiva produktif}

1.RasioVolume Pinjaman pada anggota terhadap volume pinjaman diberikan

Rumus:

$\frac{\text { Volume Pinjaman Pada Anggota }}{\text { Volume Pinjaman }} \times 100 \%$

2.Rasio Resiko Pinjaman bermasalah terhadap pinjaman yang dicairkan

Rumus:

$\frac{\text { Pinjaman Bermasalah }}{\text { Pinjaman yang diberkan }} \times 100 \%$

3.Rasio cadangan resiko terhadap pinjaman bermasalah

Rumus : $\frac{\text { cadangan resiko }}{\text { Pinjaman Bermasalah }}$ X 100\%

4.Rasio Pinjaman yang beresiko terhadap yang diberikan

Rumus

$: \frac{\text { Beban Operasi Anggota }}{\text { Volume Pinjaman }}$ X 100\%

\section{c. Efisiensi}

Rasio beban operasi anggota terhadap partisipasi bruto

Rumus $\frac{\text { Beban Operasi Anggota }}{\text { Volume Pinjaman }}$ X 100\%

\section{d. Likuiditas}

1. Rasio kas

Rumus:

$$
\frac{\text { Kas+Bank }}{\text { Kewajiban Lancar }} \times 100 \%
$$

2. Rasio Pinjaman yang diberikan terhadap dana yang diterima

Rumus

$$
: \frac{\text { Pinjaman yang diberikan }}{\text { Dana yang diterima }}
$$

\section{e. Kemandirian dan Pertumbuhan}

1.Rasio Rentabilitas Aset

$$
\text { Rumus : } \frac{\text { SHU Sebelum Pajak }}{\text { Total Asset }} \times 100 \%
$$

2.Rasio Rentabilitas Modal Sendiri

$$
\begin{aligned}
& \text { Rumus } \\
& 100 \%
\end{aligned}
$$

3.Kemandirian Operasional Pelayanan

Rumus :

$\frac{\text { Partisipasi Neto }}{\text { Beban Usaha +Beban Oprasional }} \times 100$

\section{f. Jati Diri Koperasi}

1. Rasio Partisipasi Bruto

Rumus :

$\frac{\text { Partisipasi Bruto }}{\text { Partisipasi Bruto_+ Pendapatan }} \times 100 \%$

2. Rasio promosi ekonomi anggota (PEA) 
Rumus :

$\frac{\text { PEA }}{\text { Simpanan Pokok }+ \text { Simpanan Wajib }} \times 100 \%$

Tabel 2

Penetapan Predikat Tingkat Kesehatan KSP

\begin{tabular}{|l|l|}
\hline \multicolumn{1}{|c|}{ SKOR } & PREDIKAT \\
\hline $80.00 \leq \mathrm{x} \leq 100$ & Sehat \\
\hline $66.00 \leq \mathrm{x} \leq 80.00$ & Kurang Sehat \\
\hline $51.00 \leq \mathrm{x} \leq 66.00$ & Dalam Pengawasan \\
\hline$<51.00$ & Dalam Pengawasan khusus \\
\hline
\end{tabular}

Sumber: Permen KUKM

No.06/Per/Dep.6/IV/2016

\section{HASIL PENELITIAN DAN PEMBAHASAN}

\section{Analisis Bobot Penilaian Aspek Komponen}

Analisis data yang digunakan dalam penelitian ini menggunakan analisis deskriftif kuatitatif dengan aspek penilaian kesehatan koperasi berpedoman pada peraturan Menteri Koperasi dan UKM No. 06/Per/Dep.6/IV/2016. sebagai berikut :

Tabel 3

\section{Daftar Indikator dan Bobot Aspek} Kesehatan Koperasi

\begin{tabular}{|c|l|c|}
\hline No & \multicolumn{1}{|c|}{ Indikator } & Bobot \\
\hline 1 & Permodalan & 12 \\
\hline 2 & Kualitas Aktiva Produktif & 10 \\
\hline 3 & Efisiensi & 4 \\
\hline 4 & Likuiditas & 10 \\
\hline 5 & $\begin{array}{l}\text { Kemandirian dan } \\
\text { Pertumbuhan }\end{array}$ & 7 \\
\hline 6 & Jatidiri Koperasi & 46 \\
\hline & Total Bobot & \\
\hline
\end{tabular}

\section{Bobot Penilaian Terhadap Aspek dan Komponen}

\section{Permodalan}

\section{a. Rasio Modal Sendiri terhadapTotal} Asset

Tabel 4

Rasio Modal Sendiri terhadap Total Asset

\begin{tabular}{|c|c|c|c|}
\hline Tahun & Modal Sendiri & Total Assets & Rasio \\
\hline 2016 & 420.900 .910 & 451.529 .886 & 93,21 \\
\hline 2017 & 483.009 .897 & 522.341 .578 & 92,47 \\
\hline 2018 & 673.935 .587 & 722.982 .403 & 93,21 \\
\hline \multicolumn{2}{|r|}{ Total Rasio Rata-Rata 3 Tahun } & 92,96 \\
\hline
\end{tabular}

\section{Data diolah 2019 Laporan keuangan} koperasi Kejaksaan tinggi sumsel)

Berdasarkan perhitungan pada tabel 4 diatas dimana rasio permodalan 2016 93,21\%, tahun 2017 92,47\%, terjadi penurunan Asset sebesar 0,74 \%,namun tahun 2018 rasio total asset 93,21 terjadi kenaikan kembali sebesar $0,74 \%$ dengan total rasio rata-rata sebesar $92,96 \%$

\section{Tabel 5}

\section{Penskoran Rasio Modal Sendiri} Terhadap Total Aset

\begin{tabular}{|l|c|c|c|c|c|}
\hline Rasio & Tahun & $\begin{array}{c}\text { Rasio } \\
(\boldsymbol{\%})\end{array}$ & $\begin{array}{c}\text { Nilai } \\
(\mathbf{a})\end{array}$ & $\begin{array}{c}\text { Bobot } \\
(\boldsymbol{\%}) \mathbf{( b )}\end{array}$ & $\begin{array}{c}\text { Skor } \\
(\mathbf{a}) *(\mathbf{b})\end{array}$ \\
\hline $\begin{array}{l}\text { a. Rasio } \\
\text { modal } \\
\text { sendiri } \\
\text { terhadap } \\
\text { Total } \\
\text { asset }\end{array}$ & 2016 & 93,21 & 25 & 6 & 1,50 \\
\cline { 2 - 6 } & 2018 & 92,47 & 25 & 6 & 1,50 \\
\hline
\end{tabular}

Data diolah : Lap keu koperasi kejati sumsel

Berdasarkan perhitungan rasio modal sendiri terhadap total asset, pada tahun 2016 sebesar 93,21\%: pada tahun 
201792,47 terjadi penurunan sebesar 0,73\% dan pada tahun 2018 93,21 terjadi kenaikan sebesar $0,73 \%$.

\section{b. Rasio Modal Sendiri terhadap} Pinjaman diberikan yang Berisiko,

Tabel 6

\section{Rasio Modal Sendiri terhadap Pinjaman Berisiko}

\begin{tabular}{|c|c|c|c|}
\hline Tahun & $\begin{array}{c}\text { Modal } \\
\text { Sendiri }\end{array}$ & $\begin{array}{c}\text { Pinjaman } \\
\text { Berisiko }\end{array}$ & $\begin{array}{c}\text { Rasio } \\
(\%)\end{array}$ \\
\hline 2016 & 420.900 .910 & 422.390 .941 & 97,51 \\
\hline 2017 & 483.009 .897 & 489.913 .641 & 96,69 \\
\hline 2018 & 673.935 .587 & 619.936 .191 & 106,13 \\
\hline Total & \multicolumn{2}{|c|}{ Rasio Rata-Rata 3 Tahun } & $102 ., 31$ \\
\hline
\end{tabular}

Data diolah: laporan keu kop kejati sumsel

Berdasarkan perhitungan tabel 6 diatas rasio modal sendiri terhadap pinjaman beresiko total dimana 2016 $97,51 \%$, tahun 201796,69 terjadi penurunan 0,82 tahun 2018 106,13 , dimana tahun 2018 terjadi kenaikan 9,44.dengan rasio rata-rata 102,31

Tabel 7

\section{Penskoran Rasio Modal Sendiri} terhadap Pinjaman Berisiko

\begin{tabular}{|l|c|c|c|c|c|}
\hline \multicolumn{1}{|c|}{ Rasio } & Tahun & $\begin{array}{c}\text { Rasio } \\
(\boldsymbol{\%})\end{array}$ & $\begin{array}{c}\text { Nilai } \\
(\mathbf{a})\end{array}$ & $\begin{array}{c}\text { Bobot } \\
(\boldsymbol{\%}) \mathbf{( b )}\end{array}$ & $\begin{array}{c}\text { Skor } \\
(\mathbf{a}) *(\mathbf{b})\end{array}$ \\
\hline $\begin{array}{l}\text { b. Rasio } \\
\text { Modal }\end{array}$ & 2016 & 97,51 & 100 & 6 & 5,4 \\
\cline { 2 - 6 } $\begin{array}{l}\text { Sendiri } \\
\text { terhadap } \\
\text { Pinjaman } \\
\text { Berisiko }\end{array}$ & 2017 & 96,69 & 100 & 6 & 5,4 \\
\cline { 2 - 6 } & & 106,13 & 100 & 6 & 6,0 \\
\hline
\end{tabular}

\section{Data diolah: laporan keu kop kejati}

Perincian mengenai tata cara penilaian kesehatan KSP menggunakan pedoman Berdasarkan permen KUKM No.06/Per/Dep/IV/2016 Standar
Perhitungan rasio modal sendiri terhadap pinjaman beresiko, didapat nilai 102,31. Bobot $6 \%$ dengan skor 6,0 .

\section{Kualitas Aktiva Produktif}

a. Rasio volume pinjaman pada anggota terhadap volume pinjaman diberikan :

Tabel 8

\section{Rasio Volume Pinjaman pada Anggota terhadap Total Pinjaman Diberikan}

\begin{tabular}{|c|c|c|c|}
\hline Tahun & $\begin{array}{c}\text { Volume } \\
\text { Pinjaman } \\
\text { Pada } \\
\text { Anggota }\end{array}$ & $\begin{array}{c}\text { Volume } \\
\text { Pinjaman }\end{array}$ & $\begin{array}{c}\text { Rasio } \\
(\%)\end{array}$ \\
\hline 2016 & 378.845 .841 & 493.198 .841 & 76,81 \\
\hline 2017 & 526.202 .84 & 544.335 .341 & 96,66 \\
\hline 2018 & 526.202 .841 & 608.074 .491 & 100,62 \\
\hline Total & \multicolumn{2}{|c|}{ Rasio Rata-Rata 3 tahun } & 113,14 \\
\hline
\end{tabular}

\section{Data diolah: laporan keu kop kejati} sumsel

Berdasarkan perhitungan tabel 4.9 diatas rasio total dimana $201676,81 \%$, tahun 2017 96,66 terjadi kenaikan, tahun 2018 100,62 terjadi kenaikan.Sebesar 3,96 dengan rasio rata-rata 113,14

\section{Tabel .9}

Penskoran Rasio Volume Pinjaman pada Anggota terhadap Total Pinjaman Diberikan

\begin{tabular}{|l|c|c|c|c|c|}
\hline \multicolumn{1}{|c|}{ Rasio } & Tahun & $\begin{array}{r}\text { Rasio } \\
(\%)\end{array}$ & $\begin{array}{c}\text { Nilai } \\
(\mathbf{a})\end{array}$ & $\begin{array}{c}\text { Bobot } \\
(\boldsymbol{\%})(\mathbf{b})\end{array}$ & $\begin{array}{c}\text { Skor } \\
(\mathbf{a}) *(\mathbf{b})\end{array}$ \\
\hline $\begin{array}{l}\text { a. Rasio } \\
\text { volume } \\
\text { pinjaman } \\
\text { pada } \\
\text { anggota } \\
\text { terhadap } \\
\text { volume } \\
\text { pinjaman }\end{array}$ & 2016 & 76,81 & 100 & 10 & 10,00 \\
\cline { 2 - 6 } & 2018 & 96,66 & 100 & 10 & 10,00 \\
\hline
\end{tabular}


E-ISSN : 2685-6204

Data diolah: laporan keu kop kejati sumsel

Berdasarkan perhitungan rasio volume pinjaman pada anggota terhadap volume pinjaman, pada tahun 2016 sebesar 76,21\%: pada tahun 2017 96,66 terjadi penurunan sebesar $0,73 \%$ dari tahun 2016: dan pada tahun 2018 100,62 terjadi kenaikan dari tahun 2016 sebesar $3,96 \%$.dengan rasio rata-rata sebesar 113,14 dengan Predikat Sehat

\section{Efisiensi}

a. Rasio Beban Usaha terhadap SHU kotor

Tabel 10

Rasio Beban Usaha terhadap SHU

Kotor

\begin{tabular}{|c|c|c|c|}
\hline Tahun & $\begin{array}{c}\text { Beban } \\
\text { Usaha }\end{array}$ & $\begin{array}{c}\text { SHU } \\
\text { Kotor }\end{array}$ & $\begin{array}{c}\text { Rasio } \\
(\boldsymbol{\%})\end{array}$ \\
\hline 2016 & 118.897 .000 & 93.727 .815 & 54,80 \\
\hline 2017 & 104.646 .000 & 97.151 .350 & 44,81 \\
\hline 2018 & 87.758 .863 & 85.527 .050 & 39,41 \\
\hline Total & \multicolumn{2}{|c|}{ Raio Rata-Rata 3 Tahun } & 46,34 \\
\hline
\end{tabular}

Data diolah: laporan keu kop, kejati sumsel

Berdasarkan perhitungan tabel 10 diatas dimana rasio $201654,80 \%$, tahun 2016 44,81 terjadi penurunan sebesar 9,99 tahun 2017 39,41 terjadi penurunan rasio sebesar 5,4 dengan rasio rata-rata 46,34

Tabel 11

Penskoran Rasio Beban Usaha terhadap SHU Kotor

\begin{tabular}{|c|c|c|c|c|c|}
\hline Rasio & Tahun & Rasio & $\begin{array}{c}\text { Nilai } \\
(\mathbf{a})\end{array}$ & $\begin{array}{c}\text { Bobot } \\
(\boldsymbol{\%}) \mathbf{( b )}\end{array}$ & $\begin{array}{c}\text { Skor } \\
(\mathbf{a}) *(\mathbf{b})\end{array}$ \\
\hline a. Rasio & 2015 & 54,80 & 75 & 4 & 3,00 \\
\hline
\end{tabular}

\begin{tabular}{|l|c|c|c|c|c|}
\hline Beban & 2016 & 44,81 & 75 & 4 & 3,00 \\
\cline { 2 - 6 } $\begin{array}{l}\text { Usaha } \\
\text { terhadap } \\
\text { SHU } \\
\text { Kotor }\end{array}$ & 2017 & 39,41 & 100 & 4 & 4,00 \\
\hline
\end{tabular}

Data diolah: laporan keu kop, kejati sumsel

Berdasarkan perhitungan rasio beban usaha terhadap SHU Kotor pada tahun 2016 sebesar 54,80\%; pada tahun 2017 penurunan sebesar 9,99\% dan pada trahun 2018 terjadi penurunan kembali dari tahun 2016 sebesar 5,4\%.dengan rasio ratarata sebesar 46,34

\section{Likuiditas}

a. Rasio Kas

Tabel 12

Rasio Kas

\begin{tabular}{|c|c|c|c|}
\hline Tahun & Kas + Bank & $\begin{array}{c}\text { Kewajiban } \\
\text { Lancar }\end{array}$ & $\begin{array}{c}\text { Rasio } \\
(\mathbf{\%})\end{array}$ \\
\hline 2016 & 10.662 .295 & 30.628 .976 & 34,81 \\
\hline 2017 & 9.611 .287 & 39.331 .681 & 24,43 \\
\hline 2018 & 72.927 .062 & 49.046 .816 & 148,68 \\
\hline Total & \multicolumn{2}{|l|}{ Rasio Rata-Rata 3 Tahun } & 69,30 \\
\hline
\end{tabular}

Data diolah: laporan keu kop, kejati sumsel

Berdasarkan perhitungan tabel 12 diatas rasio tahun $201634,81 \%$, tahun $201724,43 \%$ terjadi penurunan 10,38 $\%$, tahun 2018 148,68 \% terjadi kenaikan sebesar $124,25 \%$, rata-rata rasio sebessar $68,30 \%$

Berdasarkan permen

KUKM No.06/Per/Dep/IV/2016 Standar Perhitungan rasio kas terhadap kewajiban lancar, didapat nilai 69,30. Bobot 10\% dengan skor 2,5. 
Tabel 13

Penskoran Rasio Kas

\begin{tabular}{|l|c|c|c|c|c|}
\hline \multicolumn{1}{|c|}{ Rasio } & Tahun & Rasio & $\begin{array}{c}\text { Nilai } \\
(\mathbf{a})\end{array}$ & $\begin{array}{c}\text { Bobot } \\
(\boldsymbol{\%})(\mathbf{b})\end{array}$ & $\begin{array}{c}\text { Skor } \\
(\mathbf{a}) *(\mathbf{b})\end{array}$ \\
\hline $\begin{array}{l}\text { a. Rasio } \\
\text { Kas }\end{array}$ & 2016 & 34,81 & 25 & 10 & 2,5 \\
\cline { 2 - 6 } & 2017 & 24,43 & 25 & 10 & 2,5 \\
\cline { 2 - 6 } & 2018 & 148,68 & 25 & 10 & 2,5 \\
\hline
\end{tabular}

Data diolah: laporan keu kop, kejati sumsel

Berdasarkan perhitungan rasio kas pada tahun 2016 sebesar 34,81\%; pada tahun 201724,43 terjadi penurunan sebesar 10,38\%; dari tahun 2018 148,68 dan pada tahun 2018 terjadi kenaikan sebesar $124.25 \%$.

\section{Kemandirian dan Pertumbuhan}

a. Rentabilitas Aset

Tabel 14

Rasio Rentabilitas Asset

\begin{tabular}{|c|c|c|c|}
\hline Tahun & $\begin{array}{c}\text { SHU } \\
\text { Sebelum } \\
\text { Pajak }\end{array}$ & Total Aset & $\begin{array}{c}\text { Rasio } \\
(\boldsymbol{\%})\end{array}$ \\
\hline 2016 & 85.527 .050 & 457.529 .886 & 1,89 \\
\hline 2017 & 97.151 .350 & 522.341 .578 & 18,59 \\
\hline 2018 & 93.727 .815 & 722.982 .403 & 12,96 \\
\hline Total & \multicolumn{2}{|c|}{ Rasio Rata-Rata 3 Tahun } & 33,44 \\
\hline
\end{tabular}

\section{Data diolah: laporan keu kop kejati} sumsel

Berdasarkan perhitungan tabel 14 diatas rasio Rentabilitas 2016 1,89 \%, tahun $2017 \quad 18,59 \%$ terjadi kenaikan sebesar 16,7\% tahun 2017 12,9\% terjadi penurunan sebesar $5,63 \%$ dengan rasio rata-rata sebesar $33,44 \%$.

$\begin{array}{ccc}\text { Berdasarkan permen } & \text { KUKM } \\ \text { No.06/Per/Dep/IV/2016 } & \text { Standar }\end{array}$

Perhitungan rentabilitas asset didapat nilai33,44. Bobot 3\% dengan skor 3,00.

\section{Tabel 15}

Penskoran Rentabilitas Aset

\begin{tabular}{|l|c|c|c|c|c|}
\hline Rasio & Tahun & Rasio & $\begin{array}{c}\text { Nilai } \\
(\mathbf{a})\end{array}$ & $\begin{array}{c}\text { Bobot } \\
(\boldsymbol{\%})(\mathbf{b})\end{array}$ & $\begin{array}{c}\text { Skor } \\
(\mathbf{a}) *(\mathbf{b})\end{array}$ \\
\hline $\begin{array}{l}\text { a. Rasio } \\
\text { Renta } \\
\text { bilitas } \\
\text { Aset }\end{array}$ & 2016 & 1,89 & 25 & 3 & 0,75 \\
\cline { 2 - 6 } & 2017 & 18,59 & 100 & 3 & 3,00 \\
\cline { 2 - 6 } & 2018 & 12,96 & 100 & 3 & 3,00 \\
\hline
\end{tabular}

Data diolah: laporan keu kop kejatisumsel

Berdasarkan perhitungan rasio rentabilitas aset pada tahun 2016 sebesar 1,89\%; pada tahun 2017 terjadi kenaikan sebesar 16,7\% dari tahun 2016 dan pada tahun 2018 terjadi penurunan sebesar $5,63 \%$.

\section{Jatidiri Koperasi}

a. Rasio Partisipasi Bruto dihitung dengan rumus

Tabel 16

Rasio Partisipasi Bruto

\begin{tabular}{|c|c|c|c|}
\hline Tahun & $\begin{array}{c}\text { Jumlah } \\
\text { partisipasi } \\
\text { bruto }\end{array}$ & $\begin{array}{c}\text { Jumlah } \\
\text { partisipasi } \\
\text { bruto + } \\
\text { Pendapatan }\end{array}$ & $\begin{array}{c}\text { Rasio } \\
(\%)\end{array}$ \\
\hline 2016 & 103.811 .900 & 103.811 .900 & 100 \\
\hline 2017 & 121.945 .400 & 121.945 .400 & 100 \\
\hline 2018 & 118.160 .850 & 118.210 .178 & 99,95 \\
\hline Total & \multicolumn{2}{|c|}{ Rasio Rata-Rata 3 Tahun } & 99,98 \\
\hline
\end{tabular}

Data diolah: laporan keu kop kejati sumsel

Berdasarkan perhitungan tabel 16 diatas rasio $2016100 \%$, tahun 2017 100\% seimbang, tahun 2018 terjadi penurunan 
$0,05 \%$ dengan rata-rata rasio sebesar $99,98 \%$

Tabel 17

Penskoran Perhitungan Rasio Partisipasi Bruto

\begin{tabular}{|l|c|c|c|c|c|}
\hline \multicolumn{1}{|c|}{ Rasio } & Tahun & Rasio & $\begin{array}{c}\text { Nilai } \\
(\mathbf{a})\end{array}$ & $\begin{array}{c}\text { Bobot } \\
(\boldsymbol{\%})(\mathbf{b})\end{array}$ & $\begin{array}{c}\text { Skor } \\
(\mathbf{a}) *(\mathbf{b})\end{array}$ \\
\hline $\begin{array}{l}\text { a. Rasio } \\
\begin{array}{l}\text { Renta } \\
\text { bilitas } \\
\text { Aset }\end{array}\end{array}$ & 2016 & 100 & 100 & 7 & 7,00 \\
\cline { 2 - 6 } & 2017 & 100 & 100 & 7 & 7,00 \\
\cline { 2 - 6 } & 2018 & 99,95 & 100 & 7 & 7,00 \\
\hline
\end{tabular}

Data diolah: laporan keu kop kejati sumsel

Berdasarkan perhitungan Rasio Partisipasi Bruto pada tahun 2016 sebesar 100\%; pada tahun 2017 sebesar 100\%; pada tahun 201899,95 terjadi penurunan sebesar $0,05 \%$.

Hasil Penelitian Bobot Penilaian Aspek dan Komponen Kesehatan Koperasi Berdasarkan

Permen

KUKM No.06/Per/Dep/IV/2016 Pada Koperasi Kejaksaan Tinggi Sumatera Selatan.

Dari enam aspek yang dinilai dalam penilaian kesehatan koperasi yaitu aspek Permodalan, Kualitas Aktiva Produktif, Efisiensi, Likuiditas, Kemandirian dan Pertumbuhan, Jatidiri Koperasi, selanjutnya dari skor masing-masing aspek kemudian diakumulasikan untuk menentukan kriteria kesehatan koperasi.

Tabel. 18

Penilaian Kesehatan Koperasi dari Aspek Permodalan Kualitas Aktiva Produktif, Efisiensi, Likuiditas, Kemandirian dan Pertumbuhan, Jatidiri Koperas

\begin{tabular}{|c|c|c|c|c|c|}
\hline \multirow{2}{*}{$\mathbf{N}$} & \multirow{2}{*}{ Aspek yang Dinilai } & \multicolumn{3}{|c|}{ Tahun } & \multirow{2}{*}{ Rerata } \\
\hline & & 2016 & 2017 & 2018 & \\
\hline \multirow[t]{3}{*}{1} & Permodalan & 6,9 & 6,9 & 7,5 & 7,1 \\
\hline & $\begin{array}{l}\text { a. Rasio Modal } \\
\text { Sendiri }\end{array}$ & 1,50 & 1,50 & 1,50 & 1,50 \\
\hline & $\begin{array}{l}\text { b. Rasio Modal } \\
\text { Sendiri Terhadap } \\
\text { PinjamanDiberikan } \\
\text { yang Berisiko }\end{array}$ & 5,4 & 5,4 & 6,0 & 5,6 \\
\hline \multirow[t]{2}{*}{2} & $\begin{array}{l}\text { Kualitas Aktiva } \\
\text { Produktif }\end{array}$ & 10,0 & 10,0 & 10,0 & 10,0 \\
\hline & $\begin{array}{l}\text { a. Volume Pinjaman } \\
\text { Pada Anggota } \\
\text { terhadap Volume } \\
\text { Pinjaman }\end{array}$ & 10,0 & 10,0 & 10,0 & 10,0 \\
\hline \multirow[t]{2}{*}{3} & Efisiensi & 3,00 & 3,00 & 4,00 & 3,33 \\
\hline & $\begin{array}{l}\text { a. Rasio beban } \\
\text { terhadap SHU Kotor }\end{array}$ & 3,00 & 3,00 & 4,00 & 3,33 \\
\hline \multirow[t]{2}{*}{4.} & Likuiditas & 2,5 & 2,5 & 2,5 & 2,5 \\
\hline & a. Rasio Kas & 2,5 & 2,5 & 2,5 & 2,5 \\
\hline \multirow[t]{2}{*}{5.} & $\begin{array}{l}\text { Kemandirian dan } \\
\text { Pertumbuhan }\end{array}$ & 0,75 & 3,00 & 3,00 & 2,25 \\
\hline & a. Rentabilitas aset & 0,75 & 3,00 & 3,00 & 2,25 \\
\hline \multirow[t]{4}{*}{6} & Jatidiri Koperasi & $\mathbf{7 , 0 0}$ & 7,00 & 7,00 & 7,00 \\
\hline & $\begin{array}{l}\text { a. Jumlah partisipasi } \\
\text { bruto terhadap } \\
\text { jumlah partisipasi } \\
\text { bruto + pendapatan }\end{array}$ & 7,00 & 7,00 & 7,00 & 7,00 \\
\hline & Skor Akhir & 30,15 & 32,4 & 34 & 32,18 \\
\hline & $\begin{array}{l}\text { Predikat dr total } \\
\text { Aspek Tingkat } \\
\text { Kesehatan Koperasi }\end{array}$ & $\begin{array}{l}\text { Cukup } \\
\text { Sehat }\end{array}$ & $\begin{array}{l}\text { Cukup } \\
\text { Sehat }\end{array}$ & Cukup & $\begin{array}{c}\text { Cukup } \\
\text { Sehat }\end{array}$ \\
\hline
\end{tabular}

Data diolah2019 daridata sekunder Laporan keu kop kejati sumsel

\section{Aspek Permodalan}

Diperoleh skor sebesar 7,1 dengan skor rata-rata 1,50 dengan skor tertinggi maksimal 100, dan rasio diperoleh sesuai standar berada dalam rentang $\leq 51$. 
Sehingga Aspek Permodalan mendapat Predikat Dalam Pengawasan khusus.

\section{Aspek Kualitas Asset Produktif}

Diperoleh skor 10 dengan skor rata-rata 10 dengan skor tertinggi 100 dan rasio diperoleh sesuai standar berada dalam rentang $80 \leq X \leq 100$. Jadi dari Aspek Kualitas Aktiva Produktif dengan predikat sehat.

\section{Aspek Efisiensi}

Diperoleh rata-rata skor 3,33.\% dimana skor maksimal 4 sehingga mendapatkan nilai 100 , diperoleh rasio sesuai standar berada dalam rentang $80 \leq$ $\mathrm{X} \leq 100$. Jadi dari Aspek Efisiensi dengan predikat sehat.

\section{Aspek Likuiditas}

Diperoleh rata-rata skor 2,5 sehingga mendapatkan nilai 25 Skor maksimal 100, diperoleh rasio sesuai standar berada dalam rentang $\leq 51,00$. Jadi dari Aspek likuiditas dengan Predikat dalam pengawasan Khusus .

\section{Aspek Kemandirian dan Pertumbuhan}

Diperoleh rata-rata 2,25 skor maksimal 3 diperoleh berada dalam rentang $66 \leq X \leq 80$. Jadi dari Aspek Kemandirian dan Pertumbuhan dengan Predikat cukup sehat. Aspek Jati Diri diperoleh skor rata=rata 7 dimana skor maksimal 7 dimana rasio diperoleh berada dalam rentang $80 \leq X \leq 100$. Jadi dari Aspek Efisiensi dengan Predikat sehat.

\section{Kesimpulan}

untuk aspek pemodalan dalam pengawasan khusus, Aspek Kualitas aktiva produktif predikat sehat, Aspek efisiensi mendapat predikat sehat, Aspek Likuiditas dengan predikat dalam Pengawasan Khusus, Aspek kemandirian dan pertumbuhan dengan Predikat cukup sehat.

\section{Aspek jati diri}

Diproleh dengan predikat sehat. penilaian terhadap tingkat kesehatan memperoleh rerata skor sebesar 69,95.

\section{Saran}

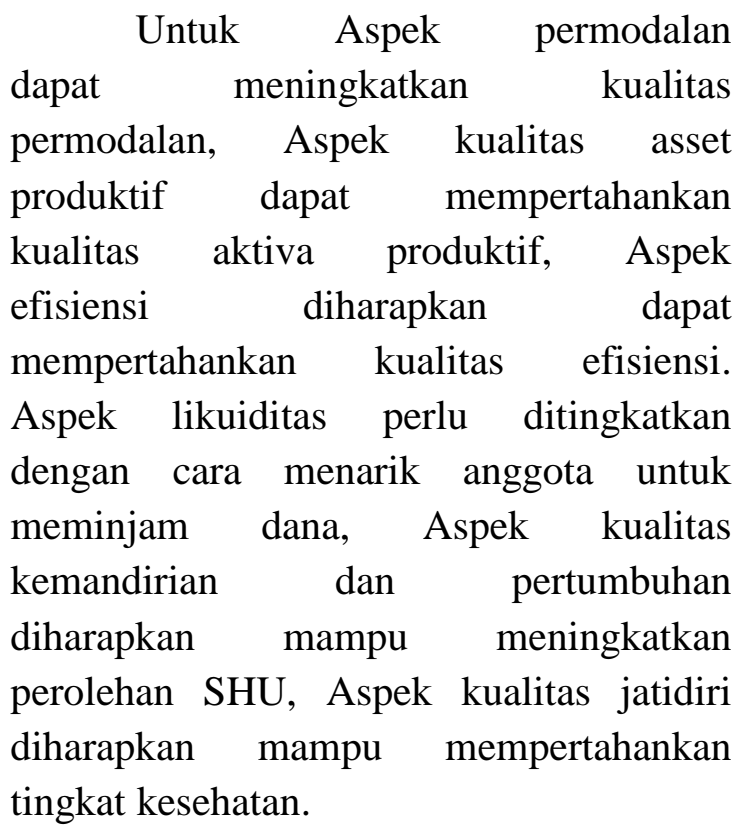

\section{DAFTAR PUSTAKA}

Fahmi, Irham. 2011. Analisis Kinerja Keuangan. Bandung: Alfabeta

Fakultas Ekonomi Universitas PGRI Palembang, 2018. Pedoman Penulisan Skripsi. Fakultas Ekonomi Universitas PGRI Palembang.

Hendra, 2010. Manajemen Perusahaan Koperasi. Jakarta: Penerbit Erlangga

Kasmir. 2012. Analisis Laporan Keuangan. Jakarta: PT Raja Grafindo Persada

Muljono, Djoko. 2013. Buku Pintar Strategi Bisnis Koperasi Simpan Pinjam. Yogyakarta : Andi 
Munawir. 2010. Analisis Laporan Keuangan. Yogyakarta: Liberty.

Nining. 2014. Analisis Kinerja Koperasi Simpan Pinjam di Kota Kediri. Skripsi Fakultas Ekonomi Universitas Kediri.

Rudianto. 2010, Akuntansi Koperasi. Jakarta: Erlangga.

Peraturan Menteri Negara Koperasi dan Usaha Kecil dan Menengah Republik Indonesia No. 14/Per/M.KIKM/XII/2009 tentang perubahan atas Peraturan Menteri Negara Koperasi dan Usaha Kecil Menengah

No.20/Per/M.KUKM/XI/2008

tentang Pedoman Penilaian Kesehatan Koperasi Simpan Pinjam dan Unit Simpan Pinjam.

Peraturan Menteri Koperasi dan Usaha Kecil dan Menengah Republik Indonesia Nomor 06/Per/Dep.6/IV/2016, tentang Pedoman Penilaian Kesehatan Koperasi Simpan Pinjam dan Usaha Kecil dan Menengah.

Praya, Lintang. 2017. Analisis Kinerja Keuangan Koperasi Simpan Pinjam dan Pembiayaan Syari'ah BMT Dana Insani. Skripsi Fakultas Ekonomi Universitas Negeri Yogyakarta.

Sugiyono, Dr, 2018. Metode Penelitian Kuantitatif, Kualitatif Dan $R \& D$,. Bandung: ALFABETA

Tanjung, M. Azrul, 2016. Koperasi Dan UMKM Sebagai Fondasi Perekonomian Indonesia. Jakarta: Erlangga.

Undang-Undang No. 25 Pasal 1 tahun1992 Tentang Perkoperasian.
Yuliansyah. 2017. Analisis Kinerja Keuangan Koperasi Simpan Pinjam Pada Koperasi "Nurul Amal" Palembang Tahun 2012-2016. Skripsi. Fakultas Ekonomi Universitas PGRI Palembang. 